\title{
High-tech entrepreneurial ventures seeking external equity: whether, when, where... and why not?
}

\author{
Anita Quas ${ }^{a}$, emlyon business school, https://orcid.org/0000-0002-6121-1931 \\ Diego D’Adda ${ }^{b}$, Universitá Politecnica delle Marche, https://orcid.org/0000-0002-1683-1787
}

\begin{abstract}
In this paper, we study the demand of high-tech entrepreneurial ventures for external equity, revealing the conditions that determine whether, when and where they decide to seek external equity during their lives. We also provide evidence on the most important reasons for not looking for external equity at all. We focus on a sample of 530 high-tech entrepreneurial ventures located in seven European countries and founded between 1984 and 2009. We reveal that company-level characteristics, namely the human capital, the innovativeness, the size, the asset intangibility, and the alternatives to equity capital (internal cash flows and debt) determine whether, when (i.e., at what age) and when (i.e., in international or domestic markets) companies seek external equity. Industry- and country-level variables also play a secondary role in explaining high-tech entrepreneurial ventures' demand for external equity.
\end{abstract}

Keywords: high-tech entrepreneurial ventures, demand for external equity, human capital, innovativeness, external financing.

JEL codes: L26, G24

Acknowledgments: We acknowledge support from the 7th EU Framework Programme VICO project on "Financing Entrepreneurial Ventures in Europe: Impact on Innovation, Employment Growth, and Competitiveness" (Contract no. SSH-2007-1.2.3-G.A. 217485).

\footnotetext{
${ }^{\text {a }}$ Corresponding author. EMLYON Business School - Department of Economics, Finance and Control. Mail: quas@em-lyon.com. Address: 23 Avenue Guy de Collongue, 69134 Ecully - France. Tel: +33 622461230

b Università Politecnica delle Marche - Dipartimento di Ingegneria dell'Informazione. Mail: Diego D'Adda dadda@dii.univpm.it. Address: Via Brecce Bianche - 60131 Ancona - Italy. Tel: +39 0712204483
} 


\title{
High-tech entrepreneurial ventures seeking external equity: whether, when, where... and why not?
}

\begin{abstract}
In this paper, we study the demand of high-tech entrepreneurial ventures for external equity, revealing the conditions that determine whether, when and where they decide to seek external equity during their lives. We also provide evidence on the most important reasons for not looking for external equity at all. We focus on a sample of 530 high-tech entrepreneurial ventures located in seven European countries and founded between 1984 and 2009. We reveal that company-level characteristics, namely the human capital, the innovativeness, the size, the asset intangibility, and the alternatives to equity capital (internal cash flows and debt) determine whether, when (i.e., at what age) and when (i.e., in international or domestic markets) companies seek external equity. Industry- and country-level variables also play a secondary role in explaining high-tech entrepreneurial ventures' demand for external equity.
\end{abstract}

Keywords: high-tech entrepreneurial ventures, demand for external equity, human capital, innovativeness, external financing.

JEL codes: L26, G24 


\section{Introduction}

The objective of this paper is to study the demand of high-tech entrepreneurial ventures for external equity, revealing the conditions that determine whether, when and where they decide to seek external equity during their lives, and why some of them do not seek at all.

Companies' preferences for the different forms of finance (namely equity and debt) have always attracted substantial interest from both policy makers and academics. Since 2008, the European Commission and the European Central Bank have administered the Survey on the Access to Finance of Enterprises (SAFE) to thousands of SMEs in the euro area. The results of the SAFE constantly reveal that bank financing is the most relevant source of external financing for small and medium companies. In 2017, 52\% of respondent SMEs declared to use bank loans to finance their businesses, while only $12 \%$ considered external equity to be a relevant source of funding (ECB 2017). Similarly, according to Robb and Robinson (2014), only around 5\% of new US-based firms receive external equity in the first 4 years of operations and most of them primarily and heavily rely on external debt, often guaranteed by the entrepreneur. These results seems to be consistent with the pecking order theory, according to which companies prefer external debt to external equity, because of the lower cost of capital (Myers and Majluf 1984).

However, debt financing is not suitable for high-tech entrepreneurial ventures. While these companies are an important source of economic growth and innovation (Acs et al. 2011), unfortunately they are also the ones that face the strongest difficulties in collecting the outside capital they need to develop their businesses. Due to information asymmetries, lenders encounter severe difficulties in the ex-ante evaluation of the potential of the entrepreneurial project and in the ex-post monitoring of the decisions made by entrepreneurs (Carpenter and Petersen 2002). The highly technical investment projects, the lack of track record and low value of tangible assets to be pledged as collateral further discourage banks to lend money to high-tech ventures (Berger and Udell 1990).

Equity capital is considered more suitable for high-tech entrepreneurial ventures because it does not require collateral, it does not accentuate moral hazard problems that are associated with leverage and it does not increase the likelihood of financial distress and failure (Carpenter and Petersen 2002). This is possible because equity investors, especially the most formal ones like venture capitalists, address information asymmetries more effectively than traditional financial intermediaries, thanks to their superior screening capabilities and the use of monitoring and staging mechanisms (Kaplan and Strömberg 2001). Moreover, equity capital entails minimal cash flow drains in the short term, which are typically associated with debt financing (Ou and Haynes 2006).

Despite its relevance, the demand for external equity of high-tech entrepreneurial ventures is largely understudied. While there are a number of papers that study the demand for external financing in general, very few focus on external equity and entrepreneurial ventures, let alone high-tech ones. Cosh et al. (2009) examine a sample of entrepreneurial firms based in the United Kingdom, and study what determines the choice whether to apply for external equity rather than debt. They find that young, high-growth innovative companies without significant assets or profits seek capital from venture capital funds more than other ventures. Riding et al. (2012) focus on young 
Canadian firms, and find that those investing in R\&D are more likely to prefer equity over debt than the others. In an Italian sample of high-tech entrepreneurial ventures, Bertoni et al. (2018a) consider how the local supply of venture capital affects the demand for external equity. Their results show that when the local venture capital market is thin, only a small fraction of firms are willing to incur in entry cost to be in the venture capital (VC) market. To the best of our knowledge, only Colombo et al. (2018) use an international setting to study the demand for external equity of high-tech entrepreneurial ventures. They reveal that entrepreneurial ventures' demand is influenced by the local availability of venture capital, but not by the characteristics of VC markets located far away and beyond national borders.

In this paper we contribute to this limited literature on the demand for external equity by high-tech entrepreneurial ventures. Specifically, we make four contributions. First, our analysis is based on an international dataset, which allows us to consider how the institutional framework in which the companies are embedded influences their demand for external equity. Second, we consider a wide set of determinants of the decision to seek external equity, at the company-, industry- and country-levels, taking inspiration from different streams of the entrepreneurial finance literature. Third, while existing evidence is limited to the determinants of companies' decision about whether to look for external equity, we also consider the decisions about when and where to look. Specifically, we exploit information about the age class during which companies looked for external equity for the first time, and whether they looked only in the domestic markets or also in the international one. Fourth, we document the most common reasons that prevent high-tech entrepreneurial ventures from seeking equity capital and link such reasons with company-, country- and industry-specific characteristics. By doing so, we aim at providing a more complete picture of the demand side of the equity financing.

Our empirical investigation is based on a sample of 530 high tech entrepreneurial ventures extracted from the VICO database. The database has been created as a part of a research project promoted by the European Commission. Our sample companies are located in 7 European countries and founded between 1984 and 2004. They answered to a survey administered in 2010 regarding their external equity seeking behavior, the timing, the geographical scope of their search and the reasons behind the decision not to seek.

In our sample, $47.55 \%$ of respondents looked for external equity during their lives. The first interesting result regards the reasons why some high-tech entrepreneurial ventures do not seek external equity: in most cases, they simply think that external equity is not needed. We then reveal that the strongest determinants of the decision to seek external equity are company-specific characteristics, namely the human capital of the founding team, the innovativeness of a company, the size, the intangibility of assets and the availability of cash flows. We also find that these factors have a different role in explaining whether, when and where a company will seek external equity. On the contrary, industry-specific and country-specific characteristics play a secondary role in determining the decision to seek external equity.

The paper proceeds as follows. In section 2, we review the existing literature we are trying to contribute. In section 3 , we describe the data and methodology used in our econometric analysis. Section 4 presents the results. Section 5 
concludes the paper summarizing our main findings and discussing the contribution to the literature, the limitations and the policy implications of this study.

\section{Literature review}

Although literature is rich in contributions looking at equity investors and at the factors driving their decision to provide equity capital (for what concerns VC see e.g., Baum and Silverman, 2004; Hall and Hofer, 1993; Petty and Gruber, 2011; Tyebjee and Bruno, 1984; Zacharakis and Meyer, 1998; Zacharakis and Shepherd, 2001), the demand-side of equity financing has received limited attention. In fact, only few studies have considered the determinants of the decision of high-tech entrepreneurial ventures to look for external equity.

As previously mentioned, Cosh et al. (2009), Riding et al. (2012), Bertoni et al. (2018a) and Colombo et al. (2018) are, to the best of our knowledge, the only studies that have specifically addressed this issue. Some other studies did not focus explicitly on equity but addressed the more general question of what drives companies' demand for external capital, which of course includes external debt (e.g., Eckhardt et al. 2006; Mina et al. 2013).

The human capital of the founding team seems to be a key driver of companies' decision to seek external finance (and equity in particular) (Bertoni, et al. 2018a; Colombo et al. 2018; Cosh et al. 2009). On the one hand, more educated and experienced founders may be better informed about the benefits (and costs) associated with external equity, and therefore more likely to apply for it. On the other hand, literature showed that companies whose founders have higher human capital, are more likely to grow and prosper (Cooper et al. 1994). Human capital may therefore be linked with the growth orientation of the company, which also has been found to positively affect external financing seeking behaviour (Cosh et al. 2009; Eckhardt et al. 2006; Mina et al. 2013; Riding et al. 2012). Moreover, Cosh et al. (2009) argue that professional leadership provides ventures with the governance required to mitigate information asymmetries and agency costs associated with financing early stage high-tech companies, and therefore increases companies' likelihood to seek external equity.

Literature also highlights a stronger need for external equity for smaller and more innovative companies. Such companies face stronger difficulties in collecting traditional forms of finance (such as credit). Smaller companies lack collateral (Berger and Udell 1990), while more innovative companies are characterized by risky projects and highly opaque growth prospects (Carpenter and Petersen 2002). As debt is not an option, smaller and more innovative ventures may be more prone to look for external equity. Ou and Haynes (2006) and Colombo et al. (2018) show results that support this claim for size and innovation, respectively.

Another company-level characteristic that has been considered by the literature on the demand for external equity is the availability of alternative sources of finance, namely cash flows and debt. According to the pecking order theory, companies should turn to equity only if internally generated funds and debt are not an option (Myers 1984). The results by Mina et al. (2013) and Colombo et al. (2018) confirm this view. 
Some works on the demand for external capital also considered the role of industry-level characteristics. Eckhardt et al. (2006) and Cosh et al. (2009) find that the level of competition in the sector in which companies operate positively predicts companies' propensity to look for external finance.

Lastly, the characteristics of the geographical area in which the ventures are embedded are key drivers of their demand for external equity in the works of Bertoni et al. (2018a) and Colombo et al. (2018). These studies focus on the supply of venture capital investments, finding that bigger venture capital markets lead to a higher propensity to look for external equity, but only when they are located nearby and within national borders.

Summing up, extant literature suggests several factors that may determine whether high-tech entrepreneurial ventures may be seeking equity capital during their lives: 1) characteristics of the companies, such as the human capital of the founding team, the innovativeness of the venture, the size, and the availability of alternative sources of finance, namely cash flows and debt;2) characteristics of the industry of operations, namely the competition; and 3) characteristics of the geographical area, such as the local supply of external equity.

Additionally, in this paper we also uncover the determinants of the decisions regarding when and where some hightech entrepreneurial ventures look for external equity and why some others do not look for external equity at all.

When to seek external equity. Ventures may apply for external equity at different stages of their development. Extant literature studied the impact of companies' age on their propensity to look for external financing, finding mixed results. Ou and Haynes (2006) and Mina et al. (2013) find that younger companies are more likely to look for external finance than older ones, coherently with the fact that companies' financing needs are highest during the "valley of death" phase that characterizes the very first years after foundation. On the contrary, Eckhardt et al. (2006) and Colombo et al. (2018) find a positive relationship between age and propensity to seek in their sample of young ventures. These seemly contradictory results may be explained by the presence of some (neglected) factors that influence the age at which ventures look for external finance for the first time. For instance, companies with higher human capital may be more grow oriented and may look for external equity earlier. Additionally, ventures operating in more $R \& D$ oriented industry may have anticipated needs for finance, to cover the high cash outflow associated with the long development process of R\&D investments. On the contrary, the presence of early positive cash flows may reduce the propensity to seek external equity at a young age. Additionally, companies may refrain from looking for equity at a very young age when they face the risk that their technology can be misappropriated by external investors, especially by those with strategic objectives like corporate venture capitalists (Colombo and Shafi 2016; Katila et al. 2008). Therefore, one may expect that companies that are able to protect their technology more effectively, thanks to stronger IPR protection mechanisms, may be looking for external equity earlier than others.

Where to seek external equity. Some entrepreneurial ventures may be even willing to actively look for external equity on foreign markets, besides domestic ones. Although cross-border equity investments have been largely studied in the existing literature (e.g., see Devigne et al. 2016; Meuleman et al. 2017 for recent examples), the decision of entrepreneurial ventures to look abroad for external equity has received little academic attention. 
Presumably, such decision is likely to bear relevant costs for a nascent venture. ${ }^{1}$ First, when looking for investors in foreign countries, entrepreneurs cannot rely on their local social relationships, which are essential for new ventures in attracting financial resources (Shane and Cable 2002; Stuart and Sorensen 2003). Second, differences in regulations and tax policies greatly increase the complexity of cross-border investments (Cumming and Macintosh 2003; Wright et al. 2005). Third, institutional and cultural differences between entrepreneurs and foreign investors exacerbate information asymmetries further increasing search costs and reduce the likelihood that the search will be successful (Li and Zahra 2012). In line with these arguments, Colombo et al. (2018) show that high-tech entrepreneurial ventures demand for external capital is hardly affected by the availability of VC beyond national borders. Nevertheless, we expect that some companies will be more likely to look for equity capital abroad than others. First, companies may be looking abroad when the conditions in the local markets are inadequate, for instance in terms of supply of capital (Tykvová and Schertler 2011), exit opportunities for investors (Bertoni and Groh 2014), or, more in general, tax and legal environment. In other words, though costly, seeking equity abroad may be necessary for promising ventures affected by unfavourable country conditions. Second, foreign investors may also entail benefits in terms of access to specific resources, which may be more valuable to some companies. For instance, Mäkelä and Maula (2005) document that foreign VC investors can help entrepreneurial ventures to expand their business into the country of the investor. Therefore, we expect the grow orientation of a company (captured for example by the quality of human capital) to push entrepreneurial ventures in this direction.

Why not to seek external equity. As to our knowledge, no previous studies have empirically studied the reasons behind the decision of entrepreneurial ventures to abstain from looking for external equity. Few studies however suggests some possible reasons. Bertoni et al.'s (2016) theoretical model implies that even good performing ventures may refrain from looking because of too high search and opportunity costs, especially in less developed market. Mason and Harrison (2001) report anecdotal evidence about the unwillingness to share ownership and control with external investors being a significant determinant of SMEs' equity aversion. Supporting this claim, Brav (2009) shows that UK private firms with less dispersed ownership, i.e., those with a stronger desire to retain control, are less likely to rely on external equity financing and have higher debt ratios. Another aspect highlighted by Mason and Harrison (2001) is the investment readiness: investor may chose not to invest "because of shortcoming of the entrepreneur and shortcomings of the business", like for example poor management team and limited growth prospects. Anticipating these shortcomings, resulting into a low probability to have access to external equity capital, entrepreneurs may refrain from looking for external equity at all. Similarly, external equity investors may require a very high risk premiums to start-ups companies, especially those characterized by high levels of information opacity. This translates into a low pre-money valuation of the venture and can represent an additional discoursing factor for looking for external equity.

${ }^{1}$ It is worth emphasizing that this issue has also relevant policy implication, especially in Europe. The European Commission has taken several steps to overcome the national barriers to cross-border investment flows, most notably through the introduction of the VC passport (European Commission 2007). 
Company-, industry-, and country-specific characteristics may have a role in explaining why some entrepreneurial ventures did not look for external equity during their lives. For instance, companies whose growth prospects are less ambitious, or that have more financial resources available, will arguably not look for external equity because additional financial resources may be superfluous. Companies with less tangible proof of their potential may instead refrain from looking for external equity because of the low probability to obtain a good offer.

\section{Data and Method}

\subsection{Sample}

We test our predictions on a cross-section sample composed of 530 European high-tech entrepreneurial ventures extracted from the VICO database. The VICO database was built thanks to the joint effort of nine universities across Europe with the support of the Seventh European Framework. Companies in the VICO database operate in seven European countries: Belgium, Finland, France, Germany, Italy, Spain and the United Kingdom. They were founded between 1984 and 2004, were independent at foundation (i.e., not controlled by other business organizations), and operate in the following high-tech manufacturing and service industries: nanotechnology; biotechnology; pharmaceuticals; computers; electronic components; telecommunications equipment; precision, optical and medical instruments; robotics; aerospace; software; telecommunications services; internet and multimedia services; web publishing; renewable energies; R\&D and engineering services. The VICO database includes two strata of ventures: 759 VC-backed ventures, extracted randomly from several databases of VC investments, and a control group of 7,611 non-VC-backed ventures that are potential targets of VC investments and have the same distribution across country, age, independence, industry, and legal status of the VC-backed companies (for more information on how the VICO database was built, see Bertoni and Martí, 2011).

In February 2010, a survey was sent to VICO companies in order to collect information about whether, when and where they sought external equity during their lives. The survey was sent to 5,417 ventures for which an email address was available. After four reminders, sent between February and April 2010, and several phone interviews aimed at filling in missing data and checking the reliability of the information provided, 814 companies eventually answered to the survey (response rate of $15.03 \%)^{2}$

In this paper, we use the data on 530 ventures for which we have complete information on the variables of interest. As the unit of analysis is the high-tech entrepreneurial venture, our final dataset includes 530 observations. Table 1 shows the distribution of sample companies by country, industry and foundation periods.

2 The distribution of survey respondents with respect to survey recipients is similar across foundation periods $\left(\chi^{2}(4)=4.061\right)$ but significantly different across countries $\left(\chi^{2}(6)=252.04\right)$ and industries $\left(\chi^{2}(6)=14.052\right)$. These differences may result in a response bias, which we take in consideration in the robustness check section of the paper. 
[Insert Table 1 around here]

\subsection{Variables and statistics}

We use four dependent variables, each corresponding to one of our research questions.

To answer to the question regarding whether entrepreneurial ventures sought equity financing, we use as dependent variable the dummy Seeking, which takes a value of 1 for companies that sought equity financing at some point in their lives and 0 otherwise. To build this variable, we used the answers that our 530 sample companies gave to the following survey question: "Has your company ever sought equity financing from sources other than founders, their family members and friends?". Of the 530 sample high-tech entrepreneurial ventures, 252 (47.55\%) had actively sought equity financing at some point in their lives.

To companies that answered "Yes" to the question regarding whether they ever looked for external equity, the survey also asked when and where they actually sought financing. To indicate when they sought external finance, respondents could select among the following nonexclusive alternatives: "before or at the time of foundation; in the first 2 years after foundation; between the $2^{\text {nd }}$ and $5^{\text {th }}$ years after foundation; between the $5^{\text {th }}$ and $10^{\text {th }}$ years after foundation; after the $10^{\text {th }}$ year after foundation". 3 The answers to such question were used to build the second dependent variable of this study, i.e., the categorical variable AgeAtSeeking. This variable is defined only if Seeking is equal to 1 and can take 5 possible values, corresponding to the earliest period during which companies sought external equity. In other terms, AgeAtSeeking indicates when the sample companies sought equity financing for the first time. Out of the 252 sample companies that sought external financing during their lives, 249 specified when. Figure 1 shows that most of sample companies looked for external equity early in their lives: $35.54 \%$ of them at foundation, $25.70 \%$ in the first 2 years after foundation, $19.68 \%$ between the $2^{\text {nd }}$ and the $5^{\text {th }}$ year after foundation, $12.45 \%$ between the $5^{\text {th }}$ and the $10^{\text {th }}$ year after foundation and the remainder $7.63 \%$ after the $10^{\text {th }}$ year after foundation.

\section{[Insert Figure 1 around here]}

As to the where companies sought equity financing, we have information on whether companies sought equity financing on the international markets, rather than only in the domestic one. Specifically, we use as third dependent variable the dummy SeekingAbroad, equal to 1 if respondents answered Yes to the question "please indicate whether your company ever sought equity financing outside national borders", and 0 otherwise. Out of the 252 sample companies that sought external financing during their lives, 217 answered to this question. 88 of them (40.55\%) declared that they sought equity financing abroad.

${ }^{3}$ To reduce retrospective bias and to increase response rates, we decided not to inquire about ventures' seeking behavior on a year-by-year basis. Instead, we collected information on ventures' external equity-seeking behavior in 5 periods of their early life, which was relatively easy for respondent to identify and remember. 
Our last dependent variable regards why not looking for external equity. Companies that answerer "No" to the question regarding whether they looked for external equity, were asked for the most important motivation for such decision. Respondents could select among the following alternatives: "other sources of financing (including cash flows from operations) have always been sufficient; obtaining equity financing was unlikely; receiving a good offer was unlikely; external shareholders would have too much control; and other”. Figure 2 shows the distribution of the 174 answers we collected for this question. Some $60.35 \%$ of respondents did not seek external equity because it was not needed: other sources of financing, including internally generated cash flows, were sufficient to finance their operations. An additional $14.94 \%$ were instead reluctant to seek external equity because of the loss of control due to the presence of external shareholders. $12.64 \%$ did not look for equity financing because they believed they would not receive good offers, and an additional $9.77 \%$ simply thought they would never receive an offer at all. We used the answers to this question to generate a categorical variable called WhyNotSeeking that takes different values depending on the selected answer. In order to increase the numerosity in each category, we aggregated the latter two reasons in a category that considers cases in which companies did not look for external equity because it was unlikely to receive a good offer, or to receive an offer at all.

\section{[Insert Figure 2 around here]}

We use several independent variables to study the determinants of entrepreneurial ventures' decisions regarding whether, when, where and why not to seek external equity. To cope with endogeneity issues and reverse causality, all independent variables are measured at the foundation.

First, to measure the human capital of founders, we use once again the results of the survey. Specifically, the survey asked sample companies whether "among the founders of the company there were individuals who, before the foundation of the company: i) had previous managerial experience, ii) had founded one or more firms, iii) had obtained an MBA or a master degree in Economics and iv) had obtained a PhD in technical or scientific disciplines". We coded the answers to these questions with 4 dummy variables, Manager, Serial, MBA and PhD_science, respectively. Unfortunately, the information on the human capital is missing for 103 companies in our sample $(19.43 \%)$. In order not to lose such observations, we impute values of human capital equal to 0 for all the variables mentioned above if the information is missing. We also include a dummy HCmissing equal to 1 if the human capital information is missing and 0 otherwise. This approach allows us to keep the 103 observations in the sample, and to correct for the change in slope in human capital variables that the arbitrary imputation of the 0 would otherwise generate (for a similar approach, see Dale and Krueger, 2002).

Second, we proxy the innovativeness of sample companies with the variable PatentApplications, equal to the number of patent applications companies had in the first year of their lives. The variable is present in the VICO database and was originally retrieved from PATSTAT.

Third, we use accounting variables, which we measure in the first year of companies' lives. InTotalAssets is equal to the logarithm of total assets $(+1)$ and captures the size at foundation of entrepreneurial ventures. Intangibles is 
equal to the ratio of intangible assets on total assets, and measures the asset intangibility of sample companies. This variable is relevant as intangible assets cannot be used as collateral and therefore limit companies' ability to rely on debt. NCFonAssets is the ratio of net cash flow generated divided by the asset of sample companies, and proxies for the internal cash generated by operations. Leverage is the ratio of financial debt (short term and long term) on total assets, and captures companies' ability to access debt. Complete accounting information is available for only 253 (47.74\%) of our sample companies. Therefore, similarly to what we do for the human capital variables, we impute the missing values of accounting variables to 0 , and control for the variable AccountingMissing in the estimates to correct for the possible bias of this data manipulation. This variable is a dummy equal to 1 if missing were imputed to 0 , and 0 otherwise. ${ }^{4}$

Fourth, we include in our models some variables measured at the industry level. Competition is the market Herfindahl concentration index in the sector of operation of sample companies (NAICS classification, 4 digits, source: Annual Survey of Manufactures and Compustat Business Segment data). We also include PatentsProtection, which measures the effectiveness of patents in protecting innovation in the investee company's sector of operations (SIC classification, 3-digit). The measure was collected by Cambridge University in a survey administered in 2004 to U.S. and U.K. manufacturing and business services firms with less than 250 employees (Cosh et al. 2011). From the same survey, we also retrieve information about the percentage of employees with scientific education in the industry, ScienceWorkforce, our proxy for the R\&D intensity of the sector.

Fifth, we consider three country-level characteristics, measured in the year of company foundation. NoIPOonGDP is the number of IPOs registered in the country of the company in the foundation year (source: Thomson One) divided by the GDP of the country (source: World Bank). The variable represents the availability of exit routes for equity investors. LegalIndex is a time invariant index developed by EVCA (now Invest Europe) in 2008 and measures to what extent the tax and legal environment in each European country favors the development of private equity, venture capital and entrepreneurship (EVCA 2008). In order to capture investor's protection in a country, we rely on the variable ShareholderRights. The variable is the "Ease of shareholder suits index" measured by World Bank in the doing business database and it is country specific. Lastly, VCfundraisingonGDP represents the supply of equity capital, and captures the annual amount raised by venture capitalists (source: Thomson One) divided by national GDP. The variable is measured in the foundation year.

Lastly, we include foundation period fixed effects by means of a set of dummies. When possible, we also consider country and industry fixed effects. In Table 2, we provide summary statistics for the independent variables, while the correlation matrix is shown in Table 3.

${ }^{4}$ Despite the smaller sample, results are similar when we do not impute missing values in human capital and accounting variables to 0 , and are available from the authors upon request. 
[Insert Table 2 and Table 3 around here]

\section{Results}

The nature of our dependent variables determines the specific econometric model chosen for the analysis. When using as dependent variables the dummy variables Seeking and SeekingAbroad, we rely on probit models. For the categorical ordinal variable AgeAtSeeking, we use instead an ordered probit model. For the categorical variable WhyNotSeeking, we use a multinomial logit. Each dependent variable is regressed against variables capturing companies' human capital, innovativeness, accounting information, characteristics of the industry and characteristics of the countries in which the companies operate. Foundation period dummies are included in all models.

Column I of Table 4 shows the results of the analysis of the determinants of the decision to seek external finance by sample companies (the dependent variable is Seeking). All our human capital variables, with the exception of Serial, have positive and significant coefficients. The average marginal effects indicate that companies whose founders had previous managerial experience, an MBA or a $\mathrm{PhD}$ in science are respectively $12.95 \%, 10.73 \%$ and $13.63 \%$ more likely to look for external equity (significant at the $1 \%, 10 \%$ and $5 \%$ level). The innovativeness of companies, captured by the number of patents applications, and the cash flows generation ability do not play a significant role, while bigger companies, with more intangibles and lower cash flows are more likely to look for external equity. A $1 \%$ increase in InTotalAssets and Intangibles lead to an increase in the probability to seek of $2.66 \%$ and $47.66 \%$ percent, respectively (significant at the $5 \%$ and $1 \%$ level). We do not find any significant coefficient for our industry-specific characteristics, while at country-level, the level of shareholder rights is positive and significant. A $1 \%$ increase in the variable ShareholderRights leads to a $4.52 \%$ increase in the likelihood to seek external equity (significant at the $1 \%$ level).

In Column II of Table 4 we show the results of a similar analysis in which we use AgeAtSeeking as dependent variable, and we restrict the sample to companies that sought external equity. In other words, we look at the timing of seeking, given that a company has actually looked for equity. In this case, we rely on an ordered probit model. For companies that sought external equity, the human capital of the founders had a limited influence on the timing of the seeking. The only significant effect is for PhD_science, which has a negative and significant coefficient, suggesting that companies with very highly educated founding team tend to look for external equity earlier in their lives. Average marginal effects indicate that the presence of a $\mathrm{PhD}$ in the founding team increases the probability to seek at foundation by $13.23 \%$, and reduce the probability to seek after the $5^{\text {th }}$ year after foundation by about $4 \%$ (depending on the category). These effects are significant at the 5\% level at least. Results show a strongly negative effect of PatentApplications, which indicates that more innovative companies seek external financing when they are younger. A $1 \%$ increase in the number of patents translates in a probability to seek equity at foundation $6.42 \%$ higher and to seek in later age classes about $2 \%$ lower (5\% significance level). We find a similar effect for companies' size, as suggested by the negative and significant coefficient of lnTotalAssets: $1 \%$ bigger companies are $2.24 \%$ more likely to seek at foundation and about $0.7 \%$ less likely to seek between the $3^{\text {rd }}$ and the $10^{\text {th }}$ year after foundation (10\% significance level). With respect to industry-level variables, we find that in sectors with larger 
science workforce, companies look for equity when they are relatively younger: a $1 \%$ increase in ScienceWorkforce leads to an increase by $0.05 \%$ in the probability to seek at foundation and a reduction by $0.02 \%$ to seek after the $3^{\text {rd }}$ year after foundation (10\% significance level). Country-level variables are not significant.

Column III of Table 4 reports the analysis of SeekingAbroad, conducted using probit models on the sample of companies that sought equity. Companies with a $\mathrm{PhD}$ in their founding team are $20.18 \%$ more likely to look abroad (significant at the $1 \%$ level), while other human capital variables are not significant. Innovation also exert a positive effect on the probability to seek equity abroad: a $1 \%$ increase in patent applications increases the chances to look abroad by $10.26 \%$ (5\% significance), while a similar increase in net cash flow over total assets reduces the chances by $11.78 \%$ (significant at the $5 \%$ level). Industry-level characteristics are not important drivers of companies' decision to look for external equity abroad, while country-level variables play a significant role. The probability to seek abroad decreases by $23.98 \%$ and increase by $5.97 \%$ respectively when the legal index and the shareholder rights index increase by $1 \%$ (5\% significance for both effects).

[Insert Table 4 around here]

Lastly, we focus on companies in our sample that did not seek external equity and study the determinants of the reasons for not seeking with a multinomial logit. As the dependent variable WhyNotSeeking has three categories, we use the reason "other sources of financing (including cash flows from operations) have always been sufficient" as reference category. Table 5 shows the determinants of the other two reasons with respect to the reference category. Specifically, we consider as alternative motivation "obtaining equity financing or receiving a good offer was unlikely" in Column $a$ and "external shareholders would have too much control" in column $b$. Interestingly, not seeking companies with more patents are less concerned about the low chances of obtaining a (good) offer (effect significant at the $1 \%$ level), but rather abstain because shareholders do not want to lose control of the company (at the 5\% level). Not surprisingly, for companies that have high net cash flow the most common reason for not seeking is the fact that external equity is not needed (the reference category), while the other two motivations are less likely (at the 5\% level). Companies with more leverage are more concerned about the low chances to obtain a (good) offer (at the 5\% level) while the competition in the industry and the availability of exit opportunities for VC investors in the country increase the chances of not seeking because of the fear of loss of control (effects significant at the $1 \%$ and $5 \%$ levels respectively).

[Insert Table 5 around here]

\subsection{Robustness checks}

We tested the robustness of our results in different ways. First, we considered alternative measures for some of our country- and industry-specific independent variables. As proxy of the innovation intensity in the sector, we substituted the variable ScienceWorkforce with a variable measuring the funds for industrial R\&D as a percentage of sales in each sector. The variable refers to the top 4 industrial R\&D-performing companies in the United States 
(source: NSF industrial R\&D data, 2007 version). For the strength of IPR protection, we substituted

PatentsProtection with a variable that also takes into account other formal measures of IPR protection, such as the registration of design, trademarks, confidentiality agreements and copyright. We retrieved information on the effectiveness of such measures in protection innovation from Cambridge University's (Cosh et al. 2011) and averaged the scores registered by all of these measures. For the ease of doing business in the country, we substituted ShareholderRights with the "Time to start a business", information that comes from the same survey carried out by World Bank (doing business database). For the VC availability, we considered only GVC fundraising instead of the fundraising from any VC investor type (VCfundraisingonGDP). The rationale is that GVC programs are specifically targeted to young and innovative companies (Bertoni et al. 2015), and may therefore influence the demand for external equity of such companies more effectively than private investors. Results based on all these alternative measures are very similar to the ones shown in the main analysis.

Second, we tested whether our results are affected by a response bias. As previously mentioned, the distribution of the respondents to our survey is different from the distribution of recipients along the country and industry dimensions. In order to correct for the potential bias that may emerge from these differences, we rely on a Heckman approach. We first estimated a probit model on the 5,417 survey recipients, in which the dependent variable is equal to 1 for the 814 respondents. We used as independent variables the age of the company in 2010, the industry and country dummies. We then used the results of the probit model to generate an Inverse Mills Ratio that corrects for the response bias (if any) in our main analyses. Additionally, we controlled for late response bias by including in the estimates a variable indicating the month during which the respondent answered to the survey (ranging from February to August). Results are unaffected by the inclusion of such correction terms.

Third, we acknowledge that in our sample countries characterized by more developed equity financial markets, such as the United Kingdom, are to some extent underrepresented. Therefore, we checked to what extent our results are driven by less important equity markets. In order to do so, we repeated the analysis on the sample of companies operating in countries in which the VC markets are most developed. We use OECD data on the VC investments in seed, start-up and early stages as a percentage of GDP in 2015 (OECD 2016) as proxy for VC development, and we identified Finland, France, Germany and UK as the most developed VC markets (early-stage VC investments ranging from $1.4 \%$ and $3.6 \%$ of GDP, as opposed to Belgium, Spain and Italy where VC investments ranging from $0.1 \%$ and $0.9 \%$ of GDP). Results indicate that the sign of the effects is maintained in the subsample of companies located in Finland, France, Germany and UK, although the coefficients are less significant, probably as a consequence of the smaller sample size.

Overall, results of our robustness checks are in line with those of the main analysis, and are omitted here for the sake of synthesis. However, they are available from the authors upon request.

\section{Discussion and conclusion}


In this paper we analyse what drives entrepreneurial ventures' choice to seek external equity financing. In particular, we study whether, when (i.e., at what age) and where (i.e., international or domestic market) a company looks for external equity. In addition, we provide evidence on the most important reasons for not looking for external equity at all. Our analysis is based on a sample of 530 high-tech entrepreneurial ventures extracted from the VICO database that answered to a survey about their external equity seeking behaviour. Sample companies were founded between 1984 and 2004, operate in high-tech sectors and are located in seven European countries.

Some $52.45 \%$ of our sample companies never looked for external equity financing. Many of these companies simply thought that external equity was not needed to fund operations. Instead, when additional external capital was needed, most discouraging factors for applying to external equity were the risk of losing control of the company and the perceived low chances to either access equity or obtaining it at convenient conditions.

We then identify the company-specific characteristics that drive the decision to seek external equity. We find that a higher level of human capital of the founding team is positively associated to such decision, with an effect that is robust and strong in magnitude. This evidence is in line with the so-called capability effect of human capital (Colombo and Grilli 2005): highly skilled entrepreneurs are more likely to found ventures based on innovative and profitable business ideas, and these ideas will need more resources in comparison with less valuable ones. In other words, on average, a higher level of founders' human capital is related with higher growth expectation, innovativeness and resource needs, especially in high-tech sectors (Colombo et al. 2004). Interestingly and consistently with Bertoni et al. (2018a), we find that economic education (i.e. an MBA) and managerial experience are associated with a higher probability of seeking external equity. However, we do not find an impact on the time at which a company seek, nor on the probability to look abroad.

Another interesting piece of evidence regarding human capital is that founders with a $\mathrm{PhD}$ in science are more likely to look for external equity, to seek earlier in their lives and more internationally. Similarly, the innovativeness of a company, in terms of the number of patent application in the first year, leads seeking companies to look for equity earlier in their lives and outside of the national borders. These results highlight how science-based ventures are more likely to need external capital early in their life (arguably to cover the expenses of long and expenses R\&D processes) and to incur in additional search costs that seeking abroad is likely to entail. The positive effect of patent applications also suggests that potential misappropriation of the technology may be a concern. Interestingly, we find that the shareholders of more innovative companies may not look for external equity for fear of losing control of the firm, while they are seldom affected by the concern of not receiving a good offer.

In addition, we also document that bigger companies (in terms of total assets) are more likely to seek external equity, especially at foundation, but less likely to seek abroad. The intangibility of assets also positively drives the choice to seek equity, but have no influence on when and where to seek. Interestingly, we find that companies that are able to generate cash flows early in their lives, are less likely to look for equity abroad. Some of them do not look for external equity at all because they already have enough financial resources. 
Industry-specific and country-specific characteristics also play a role in explaining when and where to seek external equity. Companies operating in science-oriented sectors seek equity earlier, possibly because they have to finance their R\&D processes. Companies located in countries characterized by better tax and legal environments are less likely to seek external equity abroad. The shareholders of companies operating in more competitive sectors and in countries with more developed financial markets are more concerned about the loss of control of their business, leading to the decision not to seek external equity.

These results contribute to the literature on the external finance-seeking behaviour of entrepreneurial ventures. Previous studies (Bertoni et al. 2018a; Colombo et al. 2018; Mina et al. 2013; Cosh et al. 2009; Eckhardt et al. 2006) considered some of the determinants that we have included in this work (e.g., cash generation, innovation, human capital). However, their analysis is limited to understand whether entrepreneurial ventures looked for external equity, while we also consider when and where some companies do, and why some others do not seek external equity. Additionally, unlike the majority of previous studies, we rely on an international database that encompasses several European countries and high-tech entrepreneurial ventures that were founded over a period of 20 years (1984-2004). This dataset gives us the unique opportunity to consider the financing decisions of companies that were founded in different periods and countries. Moreover, our results pertain to high-tech ventures, which arguably are the ones most affected by problems in accessing external equity (Carpenter and Petersen 2002).

We also add to the general policy discourse about the reasons why sources of external equity financing in Europe are still underused with respect to other countries, such as the US (Bertoni et al. 2015; WSBI - ESBG 2015). Most of the policy interest has been targeted to fix market failures that concern the supply side of the market. For instance, governmental venture capital programs have been set up to provide equity financing to entrepreneurial ventures that are usually neglected by private investors despite their potential (e.g., Bertoni et al. 2018b; Guerini and Quas 2016). ${ }^{5}$ However, we find that the demand side of the market is also influenced by market failures that may require governmental intervention. More than half among sample companies never sought external equity, claiming that this source of finance was not needed in $60 \%$ of the cases. One of the possible explanations for this trend is that entrepreneurs lack complete information about external equity funding sources (Ferrando et al. 2015). Our results seem to support this explanation, as we find that entrepreneurial teams with higher levels of economic education are more likely to seek. This information asymmetry may limit the demand for external funding and thereby the growth opportunities of firms, thus representing a market failure. It becomes then fundamental for policy makers to find ways to increase the awareness of entrepreneurs about the benefits associated with external equity financing, such as training programs that facilitate the development of financial capabilities and capacities (Mason and Harrison 2001). However, we also find that companies with a higher number of patents often do not look for external equity because

${ }^{5}$ On the other hand, hybrid quasi-equity forms of public intervention are also easing companies' access to debt markets (see, e.g., Martí and Quas 2018). 
of the fear of the loss of control, while companies with fewer patents are concerned regarding their chances to obtain a (good offer). These results add to the debate about whether the equity financial markets in Europe are less developed than in other developed areas because of the low quality of the demand. We find that even companies that are arguably of good quality (e.g., those that registered patents at foundation) can be reluctant to look for external equity for fear of losing control. The policy implication is that improvements in the protection of minority shareholders may help in alleviating concerns about the potential loss of control when external investors join the company. Our findings about the determinants of companies' decision to look for external equity abroad are also particularly important for policy makers. We find that only companies with very high levels of scientific human capital (namely, a PhD) and owning patents are likely to face the high costs associated with a cross-border search of equity investors. This results highlight once again the fragmentation of the European equity (and specifically venture capital) industry, which has been a concern of European policy makers (European Commission 2007).

As with any study, ours has some limitations that open up new directions for future research. The first limitation lies in the relatively small sample of the study, even if this is quite common in studies based on survey data. Although the response rate to our survey is in line with that of other similar studies (Mina et al. 2013), our final sample is limited by the availability of accounting data at foundation, despite our best efforts to collect such information. Second and relatedly, our study possibly oversamples companies located in less developed equity markets, such as Italy or Spain. Nevertheless, in a robustness check we showed that our results are similar when considering only the most developed countries in terms of equity market. Third, it is crucial in an analysis on the determinants of the demand for external equity to take into consideration the access to alternative sources of finance. In this sense, though we are able to control for the access to debt and the generation of internal capital, our dataset does not provide information about other sources like public grants. Fourth, we find limited evidence regarding the role of country-specific and industry-specific factors in affecting the demand for external equity. Part of this result may be due to the metrics used, that offer limited variation in time and across categories. In an unreported analysis, we find that some of our measures are more significant for companies born before the internet bubble (till 1999), while others are more significant after the bubble. Considering time-varying measures and extending the analysis to other countries, possibly including developing economies, would certainly bear additional interesting results.

\section{Conflict of interest statement}

On behalf of all authors, the corresponding author states that there is no conflict of interest.

\section{Bibliography}

Acs, Z. J., Audretsch, D. B., Braunerhjelm, P., \& Carlsson, B. (2011). Growth and entrepreneurship. Small Business Economics. doi:10.1007/s11187-010-9307-2

Baum, J. A. C., \& Silverman, B. S. (2004). Picking winners or building them? Alliance, intellectual, and human capital as selection criteria in venture financing and performance of biotechnology startups. Journal of Business Venturing, 19(3), 411-436. doi:10.1016/S0883-9026(03)00038-7 
Berger, A. N., \& Udell, G. F. (1990). Collateral, loan quality and bank risk. Journal of Monetary Economics, 25(1), 21-42. doi:10.1016/0304-3932(90)90042-3

Bertoni, F., Colombo, M. G., \& Quas, A. (2015). The patterns of venture capital investment in Europe. Small Business Economics, 45(3), 543-560. doi:10.1007/s11187-015-9662-0

Bertoni, F., Colombo, M. G., \& Quas, A. (2018b). The role of governmental venture capital in the venture capital ecosystem: an organizational ecology perspective. Entrepreneurship: Theory and Practice, In press, 1-19. doi: $10.1177 / 1042258717735303$

Bertoni, F., D'Adda, D., \& Grilli, L. (2016). Cherry-picking or frog-kissing? A theoretical analysis of how investors select entrepreneurial ventures in thin venture capital markets. Small Business Economics, 46(3), 391-405. doi:10.1007/s11187-015-9690-9

Bertoni, F., D'Adda, D., \& Grilli, L. (2018a). Self-selection of entrepreneurial firms in thin venture capital markets: theory and empirical evidence. Strategic Entrepreneurship Journal, In press, 1-34. doi:10.1111/sej.1280

Bertoni, F., \& Groh, A. P. (2014). Cross-Border Investments and Venture Capital Exits in Europe. Corporate Governance: An International Review, 22(2), 84-99. doi:10.1111/corg.12056

Bertoni, F., \& Martí, J. (2011). Financing Entrepreneurial Ventures in Europe: The Vico Dataset. SSRN eLibrary. doi:10.2139/ssrn.1904297

Brav, O. (2009). Access to capital, capital structure, and the funding of the firm. Journal of Finance, 64(1), 263308. doi:10.1111/j.1540-6261.2008.01434.x

Carpenter, R. E., \& Petersen, B. C. (2002). Capital Market Imperfections, High-Tech Investment, and New Equity Financing. Economic Journal, 112(477), F54-F72. doi:10.1111/1468-0297.00683

Colombo, M. G., D’Adda, D., \& Quas, A. (2018). The geography of Venture Capital: looking at the demand side.

Colombo, M. G., Delmastro, M., \& Grilli, L. (2004). Entrepreneurs' human capital and the start-up size of new technology-based firms. International Journal of Industrial Organization, 22(8-9), 1183-1211. doi:10.1016/j.ijindorg.2004.06.006

Colombo, M. G., \& Grilli, L. (2005). Founders' human capital and the growth of new technology-based firms: A competence-based view. Research Policy, 34(6), 795-816. doi:10.1016/j.respol.2005.03.010

Colombo, M. G., \& Shafi, K. (2016). Swimming with sharks in Europe : When are they dangerous and what can new ventures do to defend themselves? Strategic Management Journal, Accepted, 1-48.

Cooper, A. C., Gimeno-Gascon, F. J. J., \& Woo, C. Y. (1994). Initial human and financial capital as predictors of new venture performance. Journal of Business Venturing, 9(5), 371-395. doi:10.1016/0883-9026(94)90013-2

Cosh, A., Cumming, D. J., \& Hughes, A. (2009). Outside Entrepreneurial Capital. Economic Journal, 119(1), 494533. doi:10.1111/j.1468-0297.2009.02270.x.

Cosh, A., Jin Zhang, J., Bullock, A., \& Milner, I. (2011). Open Innovation Choices - What is British Enterprise doing?

Cumming, D. J., \& Macintosh, J. G. (2003). A cross-country comparison of full and partial venture capital exits. Journal of Banking \& Finance, 27, 511-548.

Dale, S. B., \& Krueger, A. B. (2002). Estimating the Payoff to Attending a More Selective College: An Application of Selection on Observables and Unobservables. The Quarterly Journal of Economics, 117(4), 1491-1527. 
doi:10.1162/003355302320935089

Devigne, D., Manigart, S., \& Wright, M. (2016). Escalation of commitment in venture capital decision making: Differentiating between domestic and international investors. Journal of Business Venturing, 31(3), $253-271$. doi:10.1016/j.jbusvent.2016.01.001

ECB. (2017). Survey on the Access to Finance of Enterprises in the euro area: October April to September 2017, (November). https://www.ecb.europa.eu/pub/pdf/other/ecb.accesstofinancesmallmediumsizedenterprises201711.en.pdf?beb 1832df4af9efa945a5a1f7b99eeb7

Eckhardt, J. T., Delmar, F., \& Shane, S. (2006). Multistage Selection and the Financing of New Ventures. Management Science, 52(2), 220-232. doi:10.1287/mnsc.1050.0478

European Commission. (2007). Removing obstacles to cross-border investments by venture capital funds. Brussels. http://ec.europa.eu/enterprise/newsroom/cf/itemdetail.cfm?item_id=2033

EVCA. (2008). Benchmark Paper: Benchmarking European Tax \& Legal Environments. https://www.investeurope.eu/uploadedFiles/Executive_Summary_Benchmark_2008.pdf

Ferrando, A., Iudice, M., Altomonte, C., Blank, S., Felt, M.-H., Meinen, P., et al. (2015). Assessing the financial and financing conditions of firms in Europe: the financial module in CompNet. European Central Bank Working Paper Series, August(1836), 1-94. https://www.ecb.europa.eu/pub/pdf/scpwps/ecbwp1836.en.pdf

Guerini, M., \& Quas, A. (2016). Governmental venture capital in Europe: Screening and certification. Journal of Business Venturing, 31(2), 175-195. doi:10.1016/j.jbusvent.2015.10.001

Hall, J., \& Hofer, C. W. (1993). Venture capitalists' decision criteria in new venture evaluation. Journal of Business Venturing, 8(1), 25-42. doi:10.1016/0883-9026(93)90009-T

Kaplan, S. N., \& Strömberg, P. (2001). Venture Capitalists As Principals: Contracting, Screening, and Monitoring. American Economic Review, 91(2), 426-430. doi:10.3386/w8202

Katila, R., Rosenberger, J. D., \& Eisenhardt, K. M. (2008). Swimming with Sharks: Technology Ventures, Defense Mechanisms and Corporate Relationships. Administrative Science Quarterly, 53(2), 295-332. doi:10.2189/asqu.53.2.295

Li, Y., \& Zahra, S. A. (2012). Formal institutions, culture, and venture capital activity: A cross-country analysis. Journal of Business Venturing, 27(1), 95-111. doi:10.1016/j.jbusvent.2010.06.003

Mäkelä, M. M., \& Maula, M. V. J. (2005). Cross-border venture capital and new venture internationalization: An isomorphism perspective. Venture Capital, 7(3), 227-257. doi:10.1080/13691060500258877

Martí, J., \& Quas, A. (2018). A beacon in the night: government certification of SMEs towards banks. Small Business Economics, 50(2), 397-413. doi:10.1007/s11187-016-9828-4

Mason, C. M., \& Harrison, R. T. (2001). "Investment Readiness": A Critique of Government Proposals to Increase the Demand for Venture Capital. Regional Studies, 35(7), 663-668. doi:10.1080/00343400120075939

Meuleman, M., Jääskeläinen, M., Maula, M. V. J., \& Wright, M. (2017). Venturing into the unknown with strangers: Substitutes of relational embeddedness in cross-border partner selection in venture capital syndicates. Journal of Business Venturing, 32(2), 131-144. doi:10.1016/j.jbusvent.2017.01.001

Mina, A., Lahr, H., \& Hughes, A. (2013). The demand and supply of external finance for innovative firms. Industrial and Corporate Change, 22(4), 869-901. doi:10.1093/icc/dtt020 
Myers, S. C. (1984). Capital Structure Puzzle. The Journal of Finance, 39(3), 575-592.

http://www.nber.org/papers/w1393. Accessed 26 September 2011

Myers, S. C., \& Majluf, N. S. (1984). Corporate Financing and Investment Decisions When Firms Have Information That Investors Do Not Have. Journal of Financial Economics, 13(2), 187-221. doi:10.1016/0304405X(84)90023-0

Ou, C., \& Haynes, G. W. (2006). Acquisition of Additional Equity Capital by Small Firms - Findings from the National Survey of Small Business Finances. Small Business Economics, 27(2-3), 157-168. doi:10.1007/s11187-006-0009-8

Petty, J. S., \& Gruber, M. (2011). "In pursuit of the real deal". A longitudinal study of VC decision making. Journal of Business Venturing, 26(2), 172-188. doi:10.1016/j.jbusvent.2009.07.002

Riding, A. L., Orser, B., \& Chamberlin, T. (2012). Investing in R \& D : small- and medium- sized enterprise financing preferences. Venture Capital, 14(May), 37-41. doi:10.1080/13691066.2012.654601

Robb, A. M., \& Robinson, D. T. (2014). The capital structure decisions of new firms. Review of Financial Studies, 27(1), 153-179. doi:10.1093/rfs/hhs072

Shane, S., \& Cable, D. (2002). Network Ties, Reputation, and the Financing of New Ventures. Management Science, 48(3), 364-381. doi:10.1287/mnsc.48.3.364.7731

Stuart, T. E., \& Sorensen, O. (2003). The geography of opportunity:Spatial heterogeneity in founding rates and the perfromance of biotechnology firms. Research Policy, 32, 229-253.

Tyebjee, T. T., \& Bruno, A. V. (1984). A Model of Venture Capitalist Investment Activity. Management Science, 30(9), 1051-1066. http://www.jstor.org/stable/2631723. Accessed 12 January 2011

Tykvová, T., \& Schertler, A. (2011). Cross-border venture capital flows and local ties: Evidence from developed countries. The Quarterly Review of Economics and Finance, 51(1), 36-48. doi:10.1016/j.qref.2010.09.005

Wright, M., Pruthi, S., \& Lockett, A. (2005). International venture capital research: From cross-country comparisons to crossing borders. International Journal of Management Reviews, 7(3), 135-165. doi:10.1111/j.14682370.2005.00113.x

WSBI - ESBG. (2015). Financial systems in Europe and in the US. Brussels. https://www.wsbiesbg.org/SiteCollectionDocuments/Financial systems in Europe and in the US.FINAL.pdf

Zacharakis, A. L., \& Meyer, G. D. (1998). A lack of insight: Do venture capitalists really understand their own decision process? Journal of Business Venturing, 13(1), 57-76. doi:10.1016/S0883-9026(97)00004-9

Zacharakis, A. L., \& Shepherd, D. A. (2001). The nature of information and overconfidence on venture capitalists' decision making. Journal of Business Venturing, 16(4), 311-332. doi:10.1016/S0883-9026(99)00052-X 
Tables and Figures

Figure 1: Distribution of seeking companies by age at first seeking

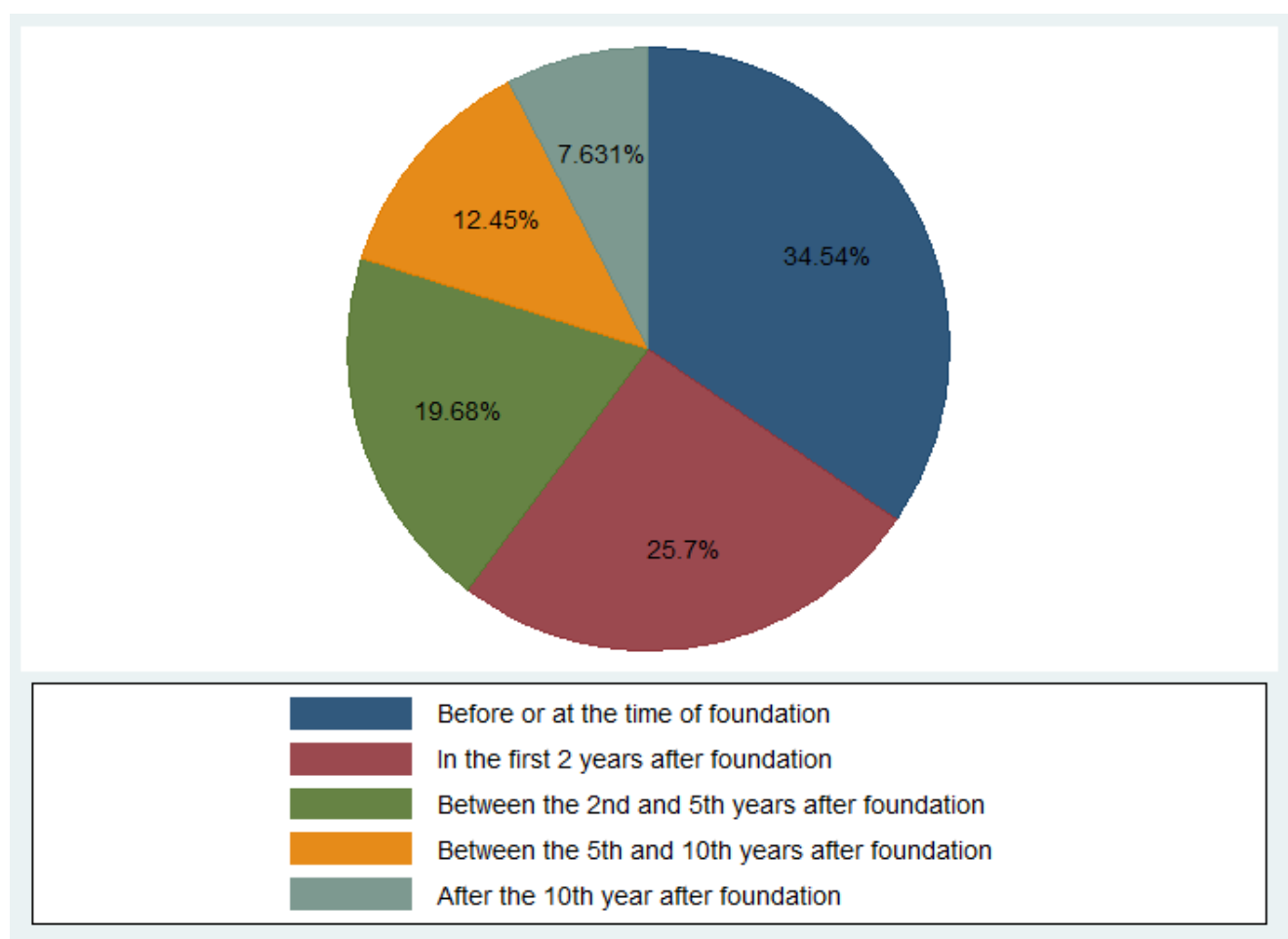

Figure 2: Distribution of non-seeking companies by reason for not seeking

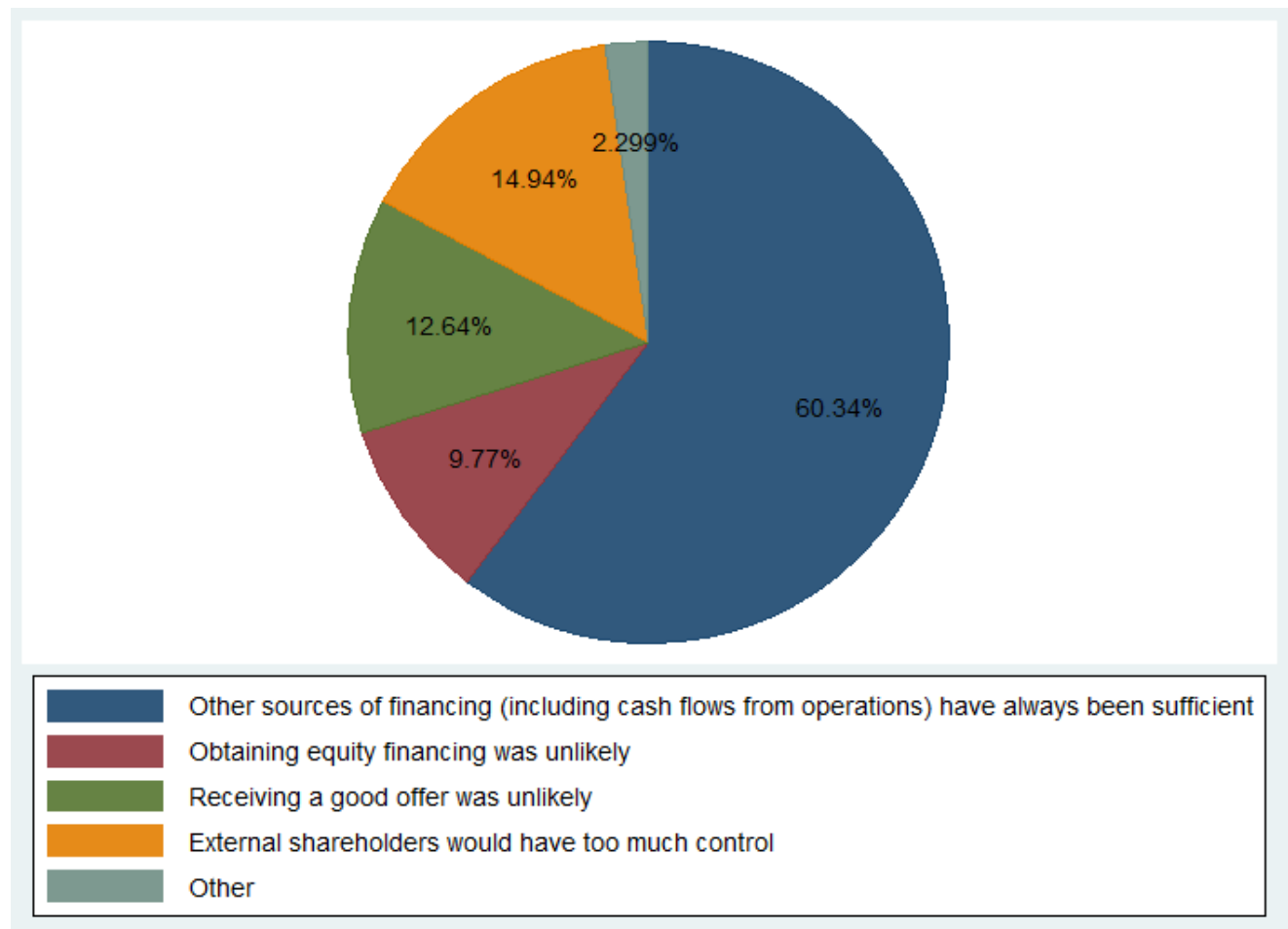


Table 1: Distribution of sample companies by country, industry and foundation period

\begin{tabular}{lrrlrr}
\hline & \multicolumn{1}{l}{ No. $\%$} & & No. $\%$ \\
Distribution by country & & & Distribution by industry & & \\
Belgium & 52 & 9.81 & Biotech, Pharmaceuticals and other R\&D & 108 & 20.38 \\
Finland & 73 & 13.77 & ICT manufacturing & 108 & 20.38 \\
France & 89 & 16.79 & Internet \& Multimedia & 29 & 5.47 \\
Germany & 28 & 5.28 & Aerospace, automotive and robotics & 35 & 6.60 \\
Italy & 97 & 18.30 & Software & 231 & 43.58 \\
Spain & 122 & 23.02 & Telecommunications & 19 & 3.58 \\
United Kingdom & 69 & 13.02 & Total & 530 & 100.00 \\
Total & 530 & 100.00 & & &
\end{tabular}

Distribution by foundation period

$\begin{array}{lrr}1984-1988 & 55 & 10.38 \\ 1989-1992 & 60 & 11.32 \\ 1993-1996 & 83 & 15.66 \\ 1997-2000 & 175 & 33.02 \\ 2001-2004 & 157 & 29.62 \\ \text { Total } & 530 & 100.00\end{array}$

Table 2: Summary statistics on independent variables

\begin{tabular}{lrrrrr}
\hline Variable & Obs & \multicolumn{2}{c}{ Mean } & Std. & Min \\
Manager & 530 & 0.515 & 0.500 & 0.000 & 1.000 \\
Serial & 530 & 0.343 & 0.475 & 0.000 & 1.000 \\
MBA & 530 & 0.153 & 0.360 & 0.000 & 1.000 \\
PhD_science & 530 & 0.221 & 0.415 & 0.000 & 1.000 \\
HCmissing & 530 & 0.194 & 0.396 & 0.000 & 1.000 \\
PatentApplications & 530 & 0.150 & 0.670 & 0.000 & 6.855 \\
InTotalAssets & 530 & 2.969 & 2.891 & 0.000 & 9.684 \\
Intangibles & 530 & 0.058 & 0.145 & 0.000 & 0.919 \\
NCFonAssets & 530 & -0.058 & 0.483 & -4.620 & 2.095 \\
Leverage & 530 & 0.051 & 0.200 & 0.000 & 2.857 \\
AccountingMissing & 530 & 0.523 & 0.500 & 0.000 & 1.000 \\
ScienceWorkforce & 530 & 39.790 & 11.325 & 16.627 & 52.942 \\
PatentsProtection & 530 & 0.742 & 0.164 & 0.538 & 1.212 \\
Competition & 530 & 0.182 & 0.141 & 0.026 & 0.726 \\
NoIPOonGDP & 530 & 0.059 & 0.074 & 0.000 & 0.345 \\
LegalIndex & 530 & 1.628 & 0.297 & 1.230 & 2.180 \\
ShareholderRights & 530 & 5.868 & 1.295 & 4.000 & 7.000 \\
VCfundraisingonGDP & 530 & 0.828 & 1.664 & 0.000 & 8.030 \\
\hline
\end{tabular}


Table 3: Correlation matrix of independent variables

The correlation matrix is based on 530 observations.

\begin{tabular}{|c|c|c|c|c|c|c|c|c|c|c|c|c|c|c|c|c|c|c|}
\hline & Variable & 1 & 2 & 3 & 4 & 5 & 6 & 7 & 8 & 9 & 10 & 11 & 12 & 13 & 14 & 15 & 16 & 17 \\
\hline 1 & Manager & 1.00 & & & & & & & & & & & & & & & & \\
\hline 2 & Serial & 0.48 & 1.00 & & & & & & & & & & & & & & & \\
\hline 3 & $M B A$ & 0.25 & 0.17 & 1.00 & & & & & & & & & & & & & & \\
\hline 4 & PhD_science & 0.07 & 0.07 & 0.24 & 1.00 & & & & & & & & & & & & & \\
\hline 5 & HCmissing & -0.51 & -0.36 & -0.21 & -0.26 & 1.00 & & & & & & & & & & & & \\
\hline 6 & PatentApplications & 0.09 & 0.01 & 0.02 & 0.19 & -0.05 & 1.00 & & & & & & & & & & & \\
\hline 7 & lnTotalAssets & 0.11 & 0.05 & 0.10 & 0.15 & -0.07 & 0.16 & 1.00 & & & & & & & & & & \\
\hline 8 & Intangibles & 0.01 & 0.00 & 0.09 & 0.07 & 0.01 & 0.08 & 0.39 & 1.00 & & & & & & & & & \\
\hline 9 & NCFonAssets & -0.08 & -0.01 & -0.08 & -0.04 & 0.05 & -0.05 & -0.07 & -0.05 & 1.00 & & & & & & & & \\
\hline 10 & Leverage & 0.09 & 0.05 & -0.03 & 0.06 & -0.06 & -0.02 & 0.20 & 0.10 & -0.24 & 1.00 & & & & & & & \\
\hline 11 & AccountingMissing & -0.01 & 0.00 & -0.05 & -0.04 & 0.02 & -0.04 & -0.82 & -0.38 & 0.09 & -0.17 & 1.00 & & & & & & \\
\hline 12 & ScienceWorkforce & -0.05 & -0.05 & 0.04 & 0.17 & -0.03 & -0.06 & 0.06 & 0.10 & -0.04 & 0.01 & -0.10 & 1.00 & & & & & \\
\hline 13 & PatentsProtection & 0.02 & 0.05 & -0.01 & 0.16 & 0.00 & 0.14 & 0.02 & -0.01 & -0.01 & 0.01 & 0.06 & -0.53 & 1.00 & & & & \\
\hline 14 & Competition & 0.00 & -0.06 & 0.00 & -0.10 & -0.02 & -0.11 & -0.35 & -0.15 & 0.07 & -0.09 & 0.31 & 0.38 & -0.43 & 1.00 & & & \\
\hline 15 & NoIPOonGDP & 0.01 & -0.02 & 0.07 & 0.16 & -0.02 & 0.14 & 0.22 & 0.06 & -0.08 & -0.01 & -0.12 & 0.11 & -0.02 & -0.22 & 1.00 & & \\
\hline 16 & LegalIndex & -0.26 & -0.20 & -0.11 & -0.27 & 0.36 & -0.13 & -0.29 & -0.11 & -0.01 & -0.05 & 0.14 & -0.07 & -0.01 & 0.04 & 0.01 & 1.00 & \\
\hline 17 & ShareholderRights & -0.12 & -0.13 & -0.05 & -0.04 & 0.24 & -0.05 & -0.03 & -0.10 & -0.04 & 0.02 & 0.02 & 0.08 & -0.06 & 0.20 & 0.21 & 0.28 & 1.00 \\
\hline 18 & VCfundraisingonGDP & 0.07 & 0.00 & 0.10 & 0.31 & -0.08 & 0.21 & 0.23 & 0.05 & -0.07 & 0.04 & -0.05 & 0.08 & 0.05 & -0.17 & 0.59 & -0.26 & 0.02 \\
\hline
\end{tabular}


Table 4: Results on the analysis of whether, when and where to seek external equity financing

The table shows coefficient and robust standard errors (in parenthesis) of regressions whose dependent variable and econometric specifications are specified in the first rows of the table. Foundation period dummies are included in all analysis but omitted for the sake of synthesis. Significance levels: $* \mathrm{p}<10 \% ; * * \mathrm{p}<5 \% ; * * * \mathrm{p}<1 \%$.

\begin{tabular}{|c|c|c|c|c|}
\hline & $\begin{array}{l}\text { Dependent variable } \\
\text { Econometric model }\end{array}$ & $\begin{array}{c}\text { I } \\
\text { Seeking } \\
\text { Probit }\end{array}$ & $\begin{array}{c}\text { II } \\
\text { AgeAtSeeking } \\
\text { Ordered Probit }\end{array}$ & $\begin{array}{l}\text { III } \\
\text { SeekingAbroad } \\
\text { Probit }\end{array}$ \\
\hline Manager & & $\begin{array}{l}0.400 * * * \\
(0.148)\end{array}$ & $\begin{array}{r}-0.100 \\
(0.179)\end{array}$ & $\begin{array}{r}0.306 \\
(0.267)\end{array}$ \\
\hline Serial & & $\begin{array}{r}-0.025 \\
(0.141)\end{array}$ & $\begin{array}{r}0.129 \\
(0.168)\end{array}$ & $\begin{array}{r}0.209 \\
(0.232)\end{array}$ \\
\hline$M B A$ & & $\begin{array}{l}0.332 * \\
(0.179)\end{array}$ & $\begin{array}{r}-0.019 \\
(0.175)\end{array}$ & $\begin{array}{r}0.037 \\
(0.217)\end{array}$ \\
\hline PhD_science & & $\begin{array}{l}0.421 * * \\
(0.169)\end{array}$ & $\begin{array}{l}-0.440 * * \\
(0.173)\end{array}$ & $\begin{array}{l}0.671 * * * \\
(0.235)\end{array}$ \\
\hline HCmissing & & $\begin{array}{l}-0.774 * * * \\
(0.199)\end{array}$ & $\begin{array}{r}0.015 \\
(0.313)\end{array}$ & $\begin{array}{r}0.000 \\
(0.000)\end{array}$ \\
\hline PatentApplications & & $\begin{array}{r}0.230 \\
(0.181)\end{array}$ & $\begin{array}{l}-0.213 * * \\
(0.106)\end{array}$ & $\begin{array}{l}0.341 * * \\
(0.148)\end{array}$ \\
\hline InTotalAssets & & $\begin{array}{l}0.082 * * \\
(0.041)\end{array}$ & $\begin{array}{l}-0.074 * \\
(0.044)\end{array}$ & $\begin{array}{r}-0.070 \\
(0.059)\end{array}$ \\
\hline Intangibles & & $\begin{array}{l}1.473 * * * \\
(0.461)\end{array}$ & $\begin{array}{r}-0.524 \\
(0.552)\end{array}$ & $\begin{array}{r}0.472 \\
(0.600)\end{array}$ \\
\hline NCFonAssets & & $\begin{array}{r}-0.168 \\
(0.138)\end{array}$ & $\begin{array}{r}0.229 \\
(0.168)\end{array}$ & $\begin{array}{l}-0.391 * * \\
(0.175)\end{array}$ \\
\hline Leverage & & $\begin{array}{l}-0.165 \\
(0.300)\end{array}$ & $\begin{array}{r}0.276 \\
(0.385)\end{array}$ & $\begin{array}{r}-0.704 \\
(0.517)\end{array}$ \\
\hline AccountingMissing & & $\begin{array}{r}0.014 \\
(0.223)\end{array}$ & $\begin{array}{r}-0.356 \\
(0.246)\end{array}$ & $\begin{array}{r}0.232 \\
(0.347)\end{array}$ \\
\hline ScienceWorkforce & & $\begin{array}{r}-0.003 \\
(0.007)\end{array}$ & $\begin{array}{l}-0.018 * \\
(0.011)\end{array}$ & $\begin{array}{r}0.014 \\
(0.014)\end{array}$ \\
\hline PatentsProtection & & $\begin{array}{l}-0.155 \\
(0.461)\end{array}$ & $\begin{array}{r}-0.695 \\
(0.572)\end{array}$ & $\begin{array}{r}0.080 \\
(0.671)\end{array}$ \\
\hline Competition & & $\begin{array}{r}0.030 \\
(0.729)\end{array}$ & $\begin{array}{r}0.795 \\
(0.924)\end{array}$ & $\begin{array}{r}0.453 \\
(1.367)\end{array}$ \\
\hline NoIPOonGDP & & $\begin{array}{r}0.122 \\
(1.211)\end{array}$ & $\begin{array}{r}-2.024 \\
(1.292)\end{array}$ & $\begin{array}{r}-0.376 \\
(1.659)\end{array}$ \\
\hline LegalIndex & & $\begin{array}{r}0.251 \\
(0.241)\end{array}$ & $\begin{array}{r}-0.316 \\
(0.305)\end{array}$ & $\begin{array}{l}-0.797 * * \\
(0.372)\end{array}$ \\
\hline ShareholderRights & & $\begin{array}{l}0.140 * * * \\
(0.051)\end{array}$ & $\begin{array}{r}0.060 \\
(0.064)\end{array}$ & $\begin{array}{l}0.199 * * \\
(0.090)\end{array}$ \\
\hline$V C f u n d r a i s i n g o n G D P$ & & $\begin{array}{r}0.058 \\
(0.054)\end{array}$ & $\begin{array}{r}0.001 \\
(0.051)\end{array}$ & $\begin{array}{r}-0.042 \\
(0.061)\end{array}$ \\
\hline Constant & & $\begin{array}{l}-1.900 * * * \\
(0.724)\end{array}$ & & $\begin{array}{r}-1.170 \\
(1.202) \\
\end{array}$ \\
\hline $\begin{array}{l}\text { N Obs. } \\
\chi^{2} \\
\text { pseudo- } R^{2}\end{array}$ & & $\begin{array}{c}530 \\
106.918 \text { *** } \\
0.179\end{array}$ & $\begin{array}{c}249 \\
103.556 * * * \\
0.117\end{array}$ & $\begin{array}{c}217 \\
54.085 * * * \\
0.211\end{array}$ \\
\hline
\end{tabular}




\section{Table 5: Results on the analysis of why not to seek external equity financing}

The table shows coefficient and robust standard errors (in parenthesis) of a multinomial logit regression whose dependent variable is WhyNotSeeking. The reason "other sources of financing (including cash flows from operations) have always been sufficient" is the reference category. "Obtaining equity financing or receiving a good offer was unlikely" is the alternative reason in column a and "external shareholders would have too much control" is he alternative reason in column b. Foundation period dummies are included in all analysis but omitted for the sake of synthesis. Significance levels: $* \mathrm{p}<10 \% ; * * \mathrm{p}<5 \% ; * * * \mathrm{p}<1 \%$.

\section{Categories}

Manager

Serial

$M B A$

PhD_science

HCmissing

PatentApplications

InTotalAssets

Intangibles

NCFonAssets

Leverage

AccountingMissing

ScienceWorkforce

PatentsProtection

Competition

NoIPOonGDP

LegalIndex

ShareholderRights

VCfundraisingon $G D P$

Constant

N Obs.

Chi2

pseudo-R2 a

I

0.251

(0.517)

0.459

(0.471)

$-1.327$

(0.931)

0.841

(0.677)

0.212

(1.494)

$-11.538 * * *$

(2.216)

0.119

$(0.160)$

$-0.458$

(3.091)

$-1.270 * *$

(0.578)

$3.238 * *$

(1.546)

$1.982 * *$

(0.856)

$-0.022$

(0.027)

$-2.691$

(1.964)

3.203

(2.518)

6.925

(6.098)

0.279

(0.887)

$-0.056$

(0.216)

$-0.106$

(0.193)

$-0.414$

(2.663)

\section{b}

$-0.429$

(0.716)

$-0.104$

(0.703)

0.340

(0.809)

0.807

(0.604)

$-12.846 * * *$

(0.978)

$2.524 * *$

(1.140)

0.297

(0.206)

$-1.519$

(2.966)

$-1.305 * *$

$(0.594)$

$-1.444$

(2.960)

$1.904 *$

(1.025)

$-0.025$

(0.028)

$-1.192$

(2.191)

8.436 ***

(3.158)

$15.498 * *$

(7.575)

$-0.863$

(1.017)

$-0.379$

(0.265)

$-1.353$

$(0.845)$

1.688

(2.949)

170

1732.598 ***

0.203 